\title{
Magnesium methanesulfonate salt found in the Dome Fuji (Antarctica) ice core
}

\author{
Toshimitsu SAKURAI, ${ }^{1}$ Hiroshi OHNO, ${ }^{2,3}$ F. Elif GENCELI, ${ }^{4}$ Shinichirou HORIKAWA, ${ }^{2}$ \\ Yoshinori IIZUKA, ${ }^{2}$ Tsutomu UCHIDA, ${ }^{5}$ Takeo $\mathrm{HONDOH}^{2}$ \\ ${ }^{1}$ Graduate School of Environmental Science, Hokkaido University, Sapporo 060-0810, Japan \\ E-mail: sakurai@lowtem.hokudai.ac.jp \\ ${ }^{2}$ Institute of Low Temperature Science, Hokkaido University, Sapporo 060-0819, Japan \\ ${ }^{3}$ Steacie Institute for Molecular Science, National Research Council, Ottawa K1A OR6, Canada \\ ${ }^{4}$ Laboratory for Process Equipment, Delft University of Technology, Leeghwaterstraat 44, 2628 CA Delft, The Netherlands \\ ${ }^{5}$ Division of Applied Physics, Graduate School of Engineering, Hokkaido University, Sapporo 060-8628, Japan
}

\begin{abstract}
Using micro-Raman spectroscopy, we identified the chemical forms of methanesulfonate salt particles in reference samples of the Dome Fuji (Antarctica) ice core. We found only $\left(\mathrm{CH}_{3} \mathrm{SO}_{3}\right) 2 \mathrm{Mg} \cdot \mathrm{nH}_{2} \mathrm{O}$ among methanesulfonate salts, and this salt particle is most prevalent in the Last Glacial Maximum (LGM) ice. We suggest that during the LGM, $\left(\mathrm{CH}_{3} \mathrm{SO}_{3}\right)_{2} \mathrm{Mg} \cdot \mathrm{nH}_{2} \mathrm{O}$ may have formed in the atmosphere through the chemical reaction of $\mathrm{CH}_{3} \mathrm{SO}_{3} \mathrm{H}$ with sea salts, but probably not in the firn and ice due to the neutralization of acid in LGM ice of inland Antarctica.
\end{abstract}

\section{INTRODUCTION}

Methanesulfonic acid $\left(\mathrm{CH}_{3} \mathrm{SO}_{3} \mathrm{H}\right)$ is an important compound formed by the oxidation of dimethyl sulfide (DMS) in the atmosphere (Hynes and others, 1986; Saigne and Legrand, 1987; Saltelli and Hjorth, 1995). $\mathrm{CH}_{3} \mathrm{SO}_{3} \mathrm{H}$ is specific to marine biogenic activity, so its concentration in the remote troposphere has been a subject of great interest over the past decade. In ice cores, $\mathrm{CH}_{3} \mathrm{SO}_{3} \mathrm{H}$ can be detected through ion chromatography $\left(\mathrm{CH}_{3} \mathrm{SO}_{3}{ }^{-}\right)$by melting an ice sample. Its anion is of primary importance as a tool for reconstructing several activities related to climate change: marine productivity (Legrand and others, 1991, 1992), sea-ice extent (Curran and others, 2003) and major El Niño events (Legrand and Feniet-Saigne, 1991).

In the present time period, ice-core $\mathrm{CH}_{3} \mathrm{SO}_{3}{ }^{-}$appears to derive mainly from post-depositional relocation, a process that occurs while the acid is in the gas and/or liquid state (Mulvaney and others, 1992; Jaffrezo and others, 1994; Pasteur and Mulvaney, 1999, 2000; McMorrow and others, 2004; Smith and others, 2004; Ruth and others, 2005). On the other hand, a recent study using Raman spectroscopy has provided new information on the chemical forms of certain water-soluble salts contained in the microparticles of ice cores. This evidence suggests that methanesulfonate may exist as a salt in glacial period ice (Ohno and others, 2005, 2006; Barletta and others, 2009). However, very little is known about the eutectic temperature and Raman spectra of methanesulfonate salts. This study identifies methanesulfonate salt particles in the Dome Fuji (Antarctica) ice core using micro-Raman spectroscopy, and proposes a formation process based on phase diagrams measured by differential scanning calorimetry (DSC) and Raman spectroscopy.

\section{METHODS}

\subsection{Chemical form of methanesulfonate salts}

Our micro-Raman spectrometer is a triple monochromator (Jobin-Yvon, T64000) equipped with a charge-coupled device (CCD) detector (Jobin-Yvon, Spectraview-2D). The device has good quantum efficiency from 500 to $900 \mathrm{~nm}$.
The spectral resolution of the Raman spectrum is $0.6 \mathrm{~cm}^{-1}$. The absolute frequency of the monochromator was calibrated using a neon emission line and silicon wafers. The cross slit of this measurement is $3 \mu \mathrm{m}$. The cryostat is posed on an $x-y-z$ translation stage, and fed by a $\mathrm{N}_{2}$ gas flow from liquid nitrogen heated inside a dewar. More detgails of the method can be found in Genceli and others (2009) and Sakurai and others (in press).

The microparticles in the Dome Fuji ice core were analyzed using micro-Raman spectroscopy. The Dome Fuji ice-core section at Termination I (the Holocene/Last Glacial Maximum (LGM) transition) was cut with a bandsaw at depths of 340.38 (Holocene), 382.86, 414.36, 463.85, 502.35 (Termination I) and $576.50 \mathrm{~m}$. The final depth corresponds to the LGM. All sections have dimensions of $10 \times 10 \times 3 \mathrm{~mm}^{3}$. The Raman spectra of microparticles in the ice core were compared with Raman spectra taken from reference specimens of simple salts such as reagent-grade chemicals $98 \mathrm{wt} \% \quad \mathrm{CH}_{3} \mathrm{SO}_{3} \mathrm{Na}$ (Alfa Aesar), $99 \mathrm{wt} \%$ $\left(\mathrm{CH}_{3} \mathrm{SO}_{3}\right)_{2} \mathrm{Mg}$ (Daniels Fine Chemicals), $98 \mathrm{wt} \% \mathrm{CH}_{3} \mathrm{SO}_{3} \mathrm{~K}$ (Tokyo Kasei Kogyo) and $98 \mathrm{wt} \%\left(\mathrm{CH}_{3} \mathrm{SO}_{3}\right)_{2} \mathrm{Ca}$ (Tokyo Kasei Kogyo) at room temperature. $\mathrm{CH}_{3} \mathrm{SO}_{3} \mathrm{Na}-\mathrm{H}_{2} \mathrm{O}$, $\left(\mathrm{CH}_{3} \mathrm{SO}_{3}\right)_{2} \mathrm{Mg}-\mathrm{H}_{2} \mathrm{O}$ and $\mathrm{CH}_{3} \mathrm{SO}_{3} \mathrm{~K}-\mathrm{H}_{2} \mathrm{O}$ were measured by Raman spectroscopy at $-30^{\circ} \mathrm{C}$, and $\left(\mathrm{CH}_{3} \mathrm{SO}_{3}\right)_{2} \mathrm{Ca}-\mathrm{H}_{2} \mathrm{O}$ was measured at $-50^{\circ} \mathrm{C}$, temperatures below the eutectic temperature, at which solid hydrated crystal salts formed. All four solutions were prepared with ultrapure water $(18.3 \mathrm{~m} \Omega)$ by weighing out the required amounts of the aforementioned reagent-grade chemicals. Due to their high percentage purities, we assume that these chemicals are anhydrous. Note that we distinguish the spectra on the basis of peak shapes as well as peak positions.

\subsection{The eutectic temperatures of methanesulfonate salts}

The phase diagrams of the methanesulfonate salts, including their eutectic temperatures, are determined using a differential scanning calorimeter (DSC; Rigaku Co., DSC8230) with liquid nitrogen cooling. Further details on the analytical technique of DSC measurement are provided by, for example, Wunderlich (1973). The temperature reproducibility of this 


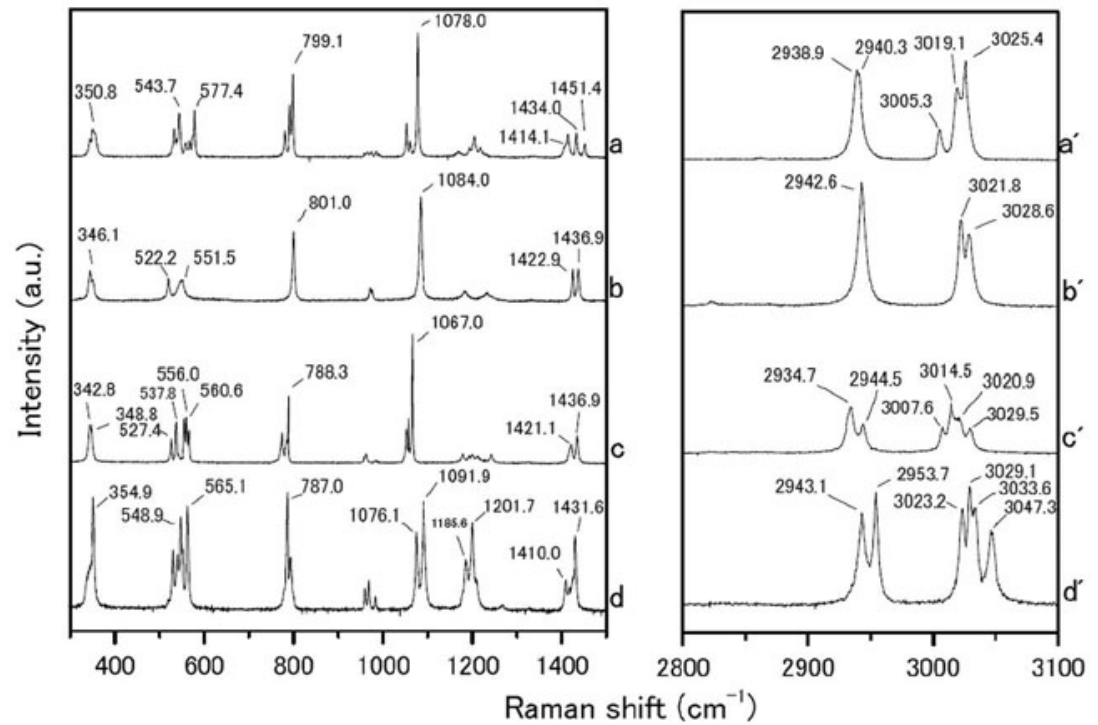

Fig. 1. Raman spectra from (a-d) $300-1500 \mathrm{~cm}^{-1}$ and $\left(\mathrm{a}^{\prime}-\mathrm{d}^{\prime}\right) 2800-3100 \mathrm{~cm}^{-1}$. (a-d) are reagent-grade crystals of $\mathrm{CH}_{3} \mathrm{SO}_{3} \mathrm{Na}_{2}\left(\mathrm{CH}_{3} \mathrm{SO}_{3}\right)_{2} \mathrm{Mg}$, $\mathrm{CH}_{3} \mathrm{SO}_{3} \mathrm{~K}$ and $\left(\mathrm{CH}_{3} \mathrm{SO}_{3}\right)_{2} \mathrm{Ca}$ respectively, which were measured at room temperature.

instrument is better than $\pm 0.2^{\circ} \mathrm{C}$, based on a three-point temperature calibration using indium $\left(156.6^{\circ} \mathrm{C}\right)$, water $\left(0.0^{\circ} \mathrm{C}\right)$ and cyclohexane $\left(-83.0^{\circ} \mathrm{C}\right)$ (Charsley, 1993).

The DSC measurements are carried out on specimens of $\mathrm{CH}_{3} \mathrm{SO}_{3} \mathrm{Na}-\mathrm{H}_{2} \mathrm{O},\left(\mathrm{CH}_{3} \mathrm{SO}_{3}\right)_{2} \mathrm{Mg}-\mathrm{H}_{2} \mathrm{O}, \mathrm{CH}_{3} \mathrm{SO}_{3} \mathrm{~K}-\mathrm{H}_{2} \mathrm{O}$ and $\left(\mathrm{CH}_{3} \mathrm{SO}_{3}\right)_{2} \mathrm{Ca}-\mathrm{H}_{2} \mathrm{O}$. Solutions are prepared by combining ultrapure water $(18.3 \mathrm{~m} \Omega)$ with reagents. The DSC cells are made of aluminum and have a capacity of $30 \mu \mathrm{L}$. In cases where the samples sublimated, the cells were sealed before use. During the measurements for $\mathrm{CH}_{3} \mathrm{SO}_{3} \mathrm{Na}-\mathrm{H}_{2} \mathrm{O}$, $\left(\mathrm{CH}_{3} \mathrm{SO}_{3}\right)_{2} \mathrm{Mg}-\mathrm{H}_{2} \mathrm{O}$ and $\mathrm{CH}_{3} \mathrm{SO}_{3} \mathrm{~K}-\mathrm{H}_{2} \mathrm{O}$, the cells were cooled to $-70^{\circ} \mathrm{C}$ at a rate of $20^{\circ} \mathrm{C} \mathrm{min}^{-1}$ and then heated to room temperature at $10^{\circ} \mathrm{Cmin}^{-1}$. These three types of samples typically had a mass of about $2 \mathrm{mg}$. The $\left(\mathrm{CH}_{3} \mathrm{SO}_{3}\right)_{2} \mathrm{Ca}-\mathrm{H}_{2} \mathrm{O}$ samples typically had a mass of about $15 \mathrm{mg}$. The $\left(\mathrm{CH}_{3} \mathrm{SO}_{3}\right)_{2} \mathrm{Ca}-\mathrm{H}_{2} \mathrm{O}$ cells were cooled to $-80^{\circ} \mathrm{C}$ at a rate of $20^{\circ} \mathrm{C} \mathrm{min}^{-1}$ and then heated to room temperature at a rate of $1^{\circ} \mathrm{C} \mathrm{min}^{-1}$. These conditions were chosen because the latent heat of $\left(\mathrm{CH}_{3} \mathrm{SO}_{3}\right)_{2} \mathrm{Ca}-\mathrm{H}_{2} \mathrm{O}$ is very low.

\section{RESULTS}

\subsection{Raman spectra of methanesulfonate salts}

We measured the Raman spectra of several reference specimens: the simple salts $\mathrm{CH}_{3} \mathrm{SO}_{3} \mathrm{Na},\left(\mathrm{CH}_{3} \mathrm{SO}_{3}\right)_{2} \mathrm{Mg}$, $\mathrm{CH}_{3} \mathrm{SO}_{3} \mathrm{~K}$ and $\left(\mathrm{CH}_{3} \mathrm{SO}_{3}\right)_{2} \mathrm{Ca}$ (Fig. 1), and their solid hydrated crystal salts with ice under eutectic conditions (Fig. 2). The methanesulfonate salts show three major peaks around $1050-1100,2930-2950$ and $3010-3030 \mathrm{~cm}^{-1}$. The peak around $1050-1100 \mathrm{~cm}^{-1}$ can be assigned to the $\mathrm{SO}_{3}{ }^{2-}$ stretching frequencies (Socrates, 2001; Barletta and others,

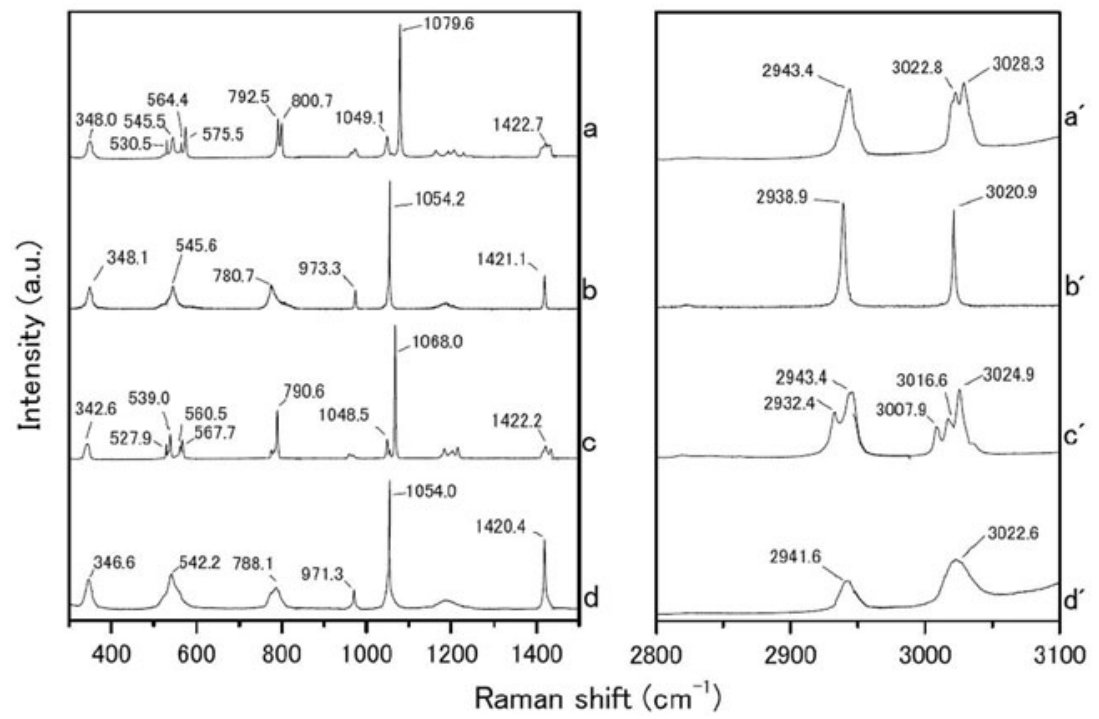

Fig. 2. Raman spectra from (a-d) $300-1500 \mathrm{~cm}^{-1}$ and $\left(\mathrm{a}^{\prime}-\mathrm{d}^{\prime}\right) 2800-3100 \mathrm{~cm}^{-1}$. (a-d) are hydrated crystals of $\mathrm{CH}_{3} \mathrm{SO}_{3} \mathrm{Na}_{2} \cdot n \mathrm{H}_{2} \mathrm{O}$, $\left(\mathrm{CH}_{3} \mathrm{SO}_{3}\right)_{2} \mathrm{Mg} \cdot n \mathrm{H}_{2} \mathrm{O}, \mathrm{CH}_{3} \mathrm{SO}_{3} \mathrm{~K} \cdot n \mathrm{H}_{2} \mathrm{O}$ and $\left(\mathrm{CH}_{3} \mathrm{SO}_{3}\right)_{2} \mathrm{Ca} \cdot n \mathrm{H}_{2} \mathrm{O}$ respectively, which formed solid hydrated crystal salt under eutectic conditions. Measurement temperatures were $-30^{\circ} \mathrm{C}$ for $\mathrm{CH}_{3} \mathrm{SO}_{3} \mathrm{Na} \cdot n \mathrm{H}_{2} \mathrm{O},\left(\mathrm{CH}_{3} \mathrm{SO}_{3}\right)_{2} \mathrm{Mg} \cdot n \mathrm{H}_{2} \mathrm{O}$ and $\mathrm{CH}_{3} \mathrm{SO}_{3} \mathrm{~K} \cdot n \mathrm{H}_{2} \mathrm{O}$, and $-50^{\circ} \mathrm{C}$ for $\left(\mathrm{CH}_{3} \mathrm{SO}_{3}\right)_{2} \mathrm{Ca} \cdot n \mathrm{H}_{2} \mathrm{O}$ 

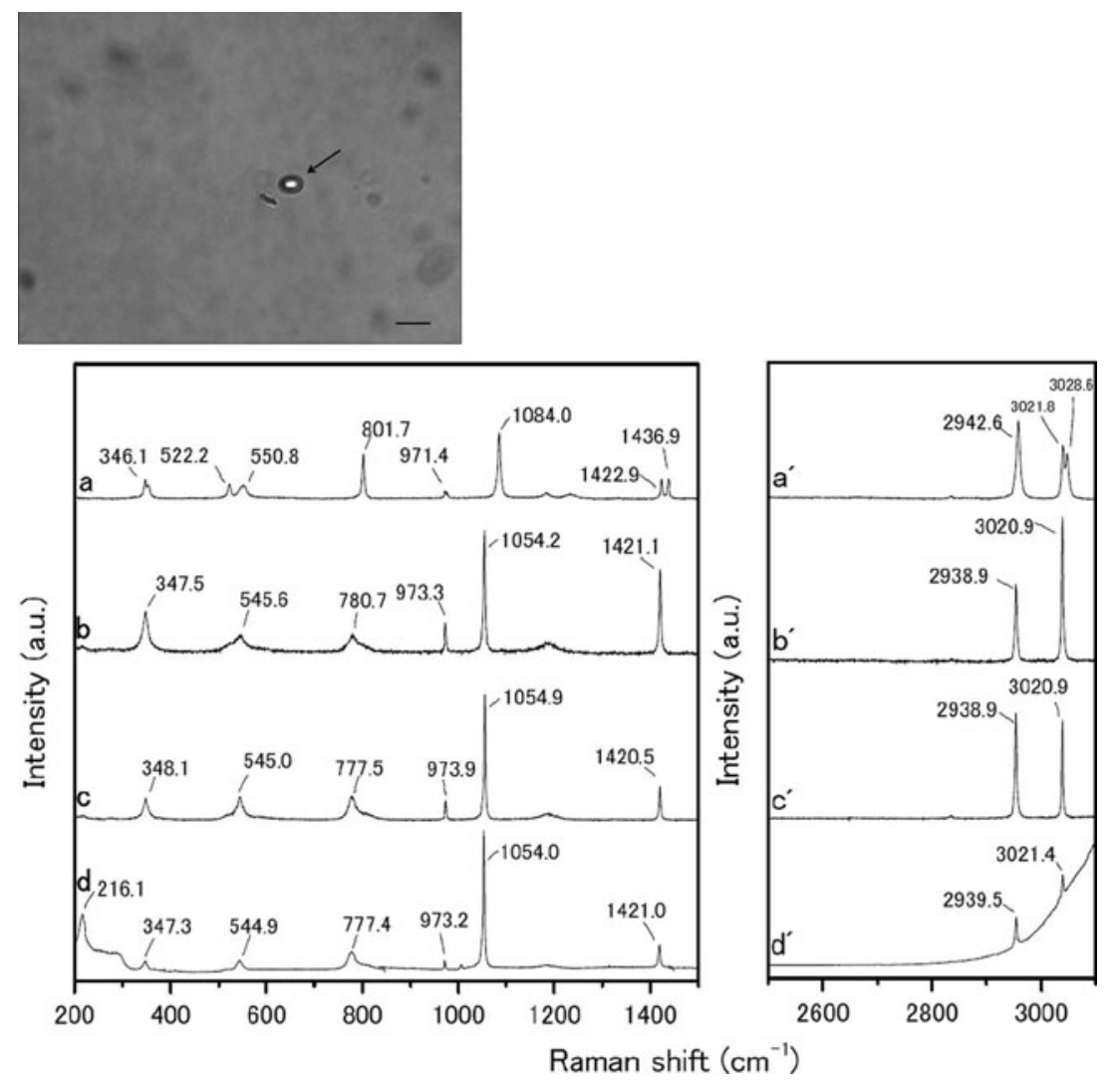

Fig. 3. Optical microscopy of a methanesulfonate salt particle (arrow) found in the ice sample at $576.5 \mathrm{~m}$ depth ( $24.5 \mathrm{ka}$ BP). The scale bar is $10 \mu \mathrm{m}$. The Raman spectra from $(a-d) 200-1500 \mathrm{~cm}^{-1}$ and $\left(a^{\prime}-d^{\prime}\right) 2500-3100 \mathrm{~cm}^{-1}$ shown below the photograph come from (a) $\left(\mathrm{CH}_{3} \mathrm{SO}_{3}\right)_{2} \mathrm{Mg}$, (b) $\left(\mathrm{CH}_{3} \mathrm{SO}_{3}\right)_{2} \mathrm{Mg} \cdot n \mathrm{H}_{2} \mathrm{O}$ (after standing at room temperature for several days and measured at $-30^{\circ} \mathrm{C}$ ), (c) $\left(\mathrm{CH}_{3} \mathrm{SO}_{3}\right)_{2} \mathrm{Mg} \cdot n \mathrm{H}_{2} \mathrm{O}$ and (d) the methanesulfonate salt inclusion from the Dome Fuji ice core (the particle in the photograph).

2009). The peaks around $2930-2950$ and $3010-3030 \mathrm{~cm}^{-1}$ can be assigned to $\mathrm{CH}_{3}$ symmetric stretching and $\mathrm{CH}_{3}$ asymmetric stretching respectively (Durig and others, 2000; Socrates, 2001; Barletta and others, 2009).

The Raman spectra of the simple salts are significantly different from those of the corresponding hydrated crystals. The differences are especially evident in the $\mathrm{SO}_{3}{ }^{2-}, \mathrm{OH}$ and $\mathrm{CH}_{3}$ stretching frequencies. The $\mathrm{SO}_{3}{ }^{2-}$ stretching mode generates a peak at $1084.0 \mathrm{~cm}^{-1}$ for the $\left(\mathrm{CH}_{3} \mathrm{SO}_{3}\right)_{2} \mathrm{Mg}$ salt. The $\left(\mathrm{CH}_{3} \mathrm{SO}_{3}\right)_{2} \mathrm{Mg}-\mathrm{H}_{2} \mathrm{O}$ solution, on the other hand, has a peak at $1054.2 \mathrm{~cm}^{-1}$. The $\mathrm{OH}$ stretching mode does not appear for any simple salt. In contrast, all the solutions have a large peak around $3000-3500 \mathrm{~cm}^{-1}$ from $\mathrm{OH}$ stretching modes. A more interesting result from these measurements relates to the $\mathrm{CH}_{3}$ symmetric and asymmetric stretching modes from 3010 to $3030 \mathrm{~cm}^{-1}$. In Raman spectra from simple salts, we detect mode splitting. For instance, the spectrum of $\left(\mathrm{CH}_{3} \mathrm{SO}_{3}\right)_{2} \mathrm{Mg}$ has peaks at 3021.8 and $3028.6 \mathrm{~cm}^{-1}$ from $\mathrm{CH}_{3}$ asymmetric stretching (Fig. 3a). The $\left(\mathrm{CH}_{3} \mathrm{SO}_{3}\right)_{2} \mathrm{Mg}-\mathrm{H}_{2} \mathrm{O}$ sample, on the other hand, produces a single sharp peak at $3020.9 \mathrm{~cm}^{-1}$. These disagreements must be caused by the crystal structure, suggesting that hydrate is forming in the methanesulfonate salt, i.e. the structure in solution is $\left(\mathrm{CH}_{3} \mathrm{SO}_{3}\right)_{2} \mathrm{Mg} \cdot n \mathrm{H}_{2} \mathrm{O}$.

\subsection{Chemical form of methanesulfonate salts in the ice core}

We found microparticles with Raman spectra very similar to those of the methanesulfonate salt $\left(\mathrm{CH}_{3} \mathrm{SO}_{3}\right)_{2} \mathrm{Mg}$. Among the six depths considered, particles of this kind are only present in LGM (576.50 m depth) ice. Furthermore, no other types of methanesulfonate salt were found among the 758 microparticles examined (Fig. 4). The microparticles of $\left(\mathrm{CH}_{3} \mathrm{SO}_{3}\right)_{2} \mathrm{Mg}$ were typically several microns in diameter (Fig. 3 photograph).

To identify the chemical form of the methanesulfonate salts present in the ice core, we compared the Raman spectra of microparticles (Fig. 3) with the reference spectra. The Raman spectra of the methanesulfonate salt particles found in the Dome Fuji ice correspond with the $\left(\mathrm{CH}_{3} \mathrm{SO}_{3}\right)_{2} \mathrm{Mg} \cdot n \mathrm{H}_{2} \mathrm{O}$ reference specimen, not with the anhydrous $\left(\mathrm{CH}_{3} \mathrm{SO}_{3}\right)_{2} \mathrm{Mg}$ specimen or any other chemical form.

The Raman spectra of $\left(\mathrm{CH}_{3} \mathrm{SO}_{3}\right)_{2} \mathrm{Ca} \cdot n \mathrm{H}_{2} \mathrm{O}$ and $\left(\mathrm{CH}_{3} \mathrm{SO}_{3}\right)_{2} \mathrm{Mg} \cdot n \mathrm{H}_{2} \mathrm{O}$ are very similar in many respects. However, they can be distinguished by their symmetric and asymmetric $\mathrm{CH}_{3}$ stretching frequencies: 2938.9 and $3020.9 \mathrm{~cm}^{-1}$ for $\left(\mathrm{CH}_{3} \mathrm{SO}_{3}\right)_{2} \mathrm{Mg} \cdot n \mathrm{H}_{2} \mathrm{O}$, or 2941.6 and $3022.6 \mathrm{~cm}^{-1}$ for $\left(\mathrm{CH}_{3} \mathrm{SO}_{3}\right)_{2} \mathrm{Ca} \cdot n \mathrm{H}_{2} \mathrm{O}$. We used Gaussian fitting to estimate the positions and half-bandwidths of the peaks. The corresponding peaks in Raman spectra obtained from methanesulfonate salt particles in the ice core are located at 2938.9 and $3020.9 \mathrm{~cm}^{-1}$. The halfbandwidths of the peaks are $3.9 \pm 0.1$ and $2.9 \pm 0.9 \mathrm{~cm}^{-1}$ respectively. The peak locations and half-bandwidths of the $\left(\mathrm{CH}_{3} \mathrm{SO}_{3}\right)_{2}-\mathrm{Ca} \cdot n \mathrm{H}_{2} \mathrm{O}$ reference hydrated crystal are $2941.6 \mathrm{~cm}^{-1}, \quad 3023.1 \mathrm{~cm}^{-1}$ and $15.8 \pm 0.2 \mathrm{~cm}^{-1}$, $23.7 \pm 3.4 \mathrm{~cm}^{-1}$ respectively. This evidence strongly suggests that the methanesulfonate salt found in the ice core is $\left(\mathrm{CH}_{3} \mathrm{SO}_{3}\right)_{2} \mathrm{Mg} \cdot n \mathrm{H}_{2} \mathrm{O}$ and not $\left(\mathrm{CH}_{3} \mathrm{SO}_{3}\right)_{2} \mathrm{Ca} \cdot n \mathrm{H}_{2} \mathrm{O}$. 


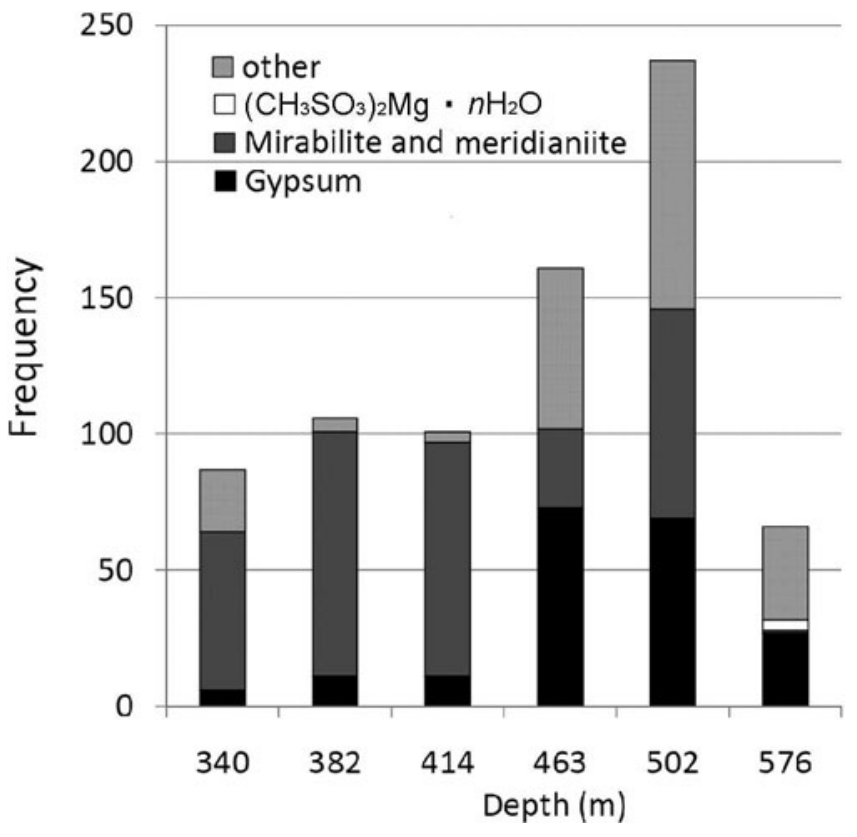

Fig. 4. The distribution of microparticle types found in ice samples taken from Termination I of the Dome Fuji ice core. The climate ranges are $340 \mathrm{~m}$ (Holocene), 382-502 m (Termination I) and $576 \mathrm{~m}$ (LGM). The numbers of microparticles measured at each depth are 87, 106, 101, 161, 237 and 66 (a total of 758 particles). The numbers of microparticles in the 'gypsum' category are 6, 11, 11, 73, 69 and 27 respectively. The numbers in the 'mirabilite and meridianiite' category are 58, 90, 86, 29, 77 and 1 respectively. Only four $\left(\mathrm{CH}_{3} \mathrm{SO}_{3}\right)_{2} \mathrm{Mg} \cdot n \mathrm{H}_{2} \mathrm{O}$ microparticles were found, and these only in the LGM.

To evaluate the structural phase transition during preservation, we left the $\left(\mathrm{CH}_{3} \mathrm{SO}_{3}\right)_{2} \mathrm{Mg}-\mathrm{H}_{2} \mathrm{O}$ solution in a Petri dish at room temperature for several days to sublimate the water, then measured the Raman spectrum of the sample. The resulting spectrum remains clearly $\left(\mathrm{CH}_{3} \mathrm{SO}_{3}\right)_{2} \mathrm{Mg} \cdot n \mathrm{H}_{2} \mathrm{O}$, not $\left(\mathrm{CH}_{3} \mathrm{SO}_{3}\right)_{2} \mathrm{Mg}$ (Fig. $3 \mathrm{~b}$ and c). This result suggests that once $\left(\mathrm{CH}_{3} \mathrm{SO}_{3}\right)_{2} \mathrm{Mg} \cdot n \mathrm{H}_{2} \mathrm{O}$ has formed it can be preserved as a structure of hydrate. It further suggests that a structural phase transition to the anhydrous state or some other phase could not have occurred.

\subsection{Phase diagrams of methanesulfonate salts}

The phase transitions of $\mathrm{CH}_{3} \mathrm{SO}_{3} \mathrm{Na}-\mathrm{H}_{2} \mathrm{O}$, $\left(\mathrm{CH}_{3} \mathrm{SO}_{3}\right)_{2} \mathrm{Mg}-\mathrm{H}_{2} \mathrm{O}, \mathrm{CH}_{3} \mathrm{SO}_{3} \mathrm{~K}-\mathrm{H}_{2} \mathrm{O}$ and $\left(\mathrm{CH}_{3} \mathrm{SO}_{3}\right)_{2} \mathrm{Ca}-\mathrm{H}_{2} \mathrm{O}$ generate typical DSC profiles during the heating process. The phase diagrams of the solutions are shown in Figure 5.

\section{$\mathrm{CH}_{3} \mathrm{SO}_{3} \mathrm{Na}-\mathrm{H}_{2} \mathrm{O}$}

We performed measurements in the composition range $0-52 \mathrm{wt} \%$ (Fig. 5a). The eutectic temperature of this salt is $-29.3 \pm 0.2^{\circ} \mathrm{C}$. Concentrations higher than $50 \mathrm{wt} \%$ $\mathrm{CH}_{3} \mathrm{SO}_{3} \mathrm{Na}-\mathrm{H}_{2} \mathrm{O}$ were deposited from the solution at room temperature. The enthalpy of fusion at the eutectic composition of $50 \mathrm{wt} \%$ is $\Delta \mathrm{H}_{\mathrm{Na}}=12.6 \pm 0.9 \mathrm{~kJ} \mathrm{~mol}^{-1}$.

\section{$\left(\mathrm{CH}_{3} \mathrm{SO}_{3}\right) \mathrm{Mg}-\mathrm{H}_{2} \mathrm{O}$}

We performed measurements in the composition range $0-36 \mathrm{wt} \%$ (Fig. 5b). The average eutectic transition temperature over all samples is $-5.0 \pm 0.5^{\circ} \mathrm{C}$. Above a solute concentration of $14 \mathrm{wt} \%$, salt deposition occurred at room temperature. The enthalpy of fusion at the eutectic composition of $14 \mathrm{wt} \%$ is $\Delta \mathrm{H}_{\mathrm{Mg}}=13.3 \pm 0.04 \mathrm{~kJ} \mathrm{~mol}^{-1}$.

\section{$\mathrm{CH}_{3} \mathrm{SO}_{3} \mathrm{~K}-\mathrm{H}_{2} \mathrm{O}$}

We performed measurements in the composition range 0-60 wt\% (Fig. 5C). The average eutectic transition temperature is $-17.8 \pm 0.1^{\circ} \mathrm{C}$. The enthalpy of fusion at the eutectic composition of $44 \mathrm{wt} \%$ is $\Delta \mathrm{H}_{\mathrm{K}}=17.9 \pm 0.08 \mathrm{~kJ} \mathrm{~mol}^{-1}$.

\section{$\left(\mathrm{CH}_{3} \mathrm{SO}_{3}\right)_{2} \mathrm{Ca}-\mathrm{H}_{2} \mathrm{O}$}

We performed measurements in the composition range $0-44 \mathrm{wt} \%$ (Fig. 5d). The average eutectic transition temperature is $-32.6 \pm 0.2^{\circ} \mathrm{C}$. At compositions of $44 \mathrm{wt} \%$ or higher, our measurements of this compound were not easily reproducible (although the other three species were detectable at their eutectic compositions). We therefore do not have a good estimate for the enthalpy of fusion, but one profile gave $\Delta \mathrm{H}_{\mathrm{Ca}}=0.46 \pm 0.04 \mathrm{~kJ} \mathrm{~mol}^{-1}$.

\section{DISCUSSION}

The eutectic temperature of $\left(\mathrm{CH}_{3} \mathrm{SO}_{3}\right)_{2} \mathrm{Mg} \cdot n \mathrm{H}_{2} \mathrm{O}$ $\left(-5.0 \pm 0.5^{\circ} \mathrm{C}\right)$ is much higher than any temperature within the Dome Fuji ice core, from the surface to the lowest depth. The average temperature of the core at $10 \mathrm{~m}$ depth is $-58^{\circ} \mathrm{C}$, and the deepest recorded temperature (from the first Dome Fuji ice-core project, at $2503 \mathrm{~m}$ ) is $\sim-10^{\circ} \mathrm{C}$ (Hondoh and others, 2002). This result indicates that $\left(\mathrm{CH}_{3} \mathrm{SO}_{3}\right)_{2} \mathrm{Mg} \cdot n \mathrm{H}_{2} \mathrm{O}$ is thermodynamically stable in the Dome Fuji ice core between the surface and $2503 \mathrm{~m}$. We shall now propose two formation mechanisms for $\left(\mathrm{CH}_{3} \mathrm{SO}_{3}\right) \mathrm{Mg} \cdot n \mathrm{H}_{2} \mathrm{O}$ in Antarctica, one in the ice-sheet firn and the other in the polar atmosphere.

$\mathrm{CH}_{3} \mathrm{SO}_{3} \mathrm{H}$ is formed by the oxidation of DMS, which is emitted by biological activity (e.g. Saltelli and Hjorth, 1995) on the open sea. Sea salts are emitted by sea spray and probably from surface sea ice (e.g. Rankin and others, 2002). The chemical reaction of $\mathrm{CH}_{3} \mathrm{SO}_{3} \mathrm{H}$ with sea salt can form methanesulfonate salt. In previous studies using ion chromatography on coastal ice cores obtained at Dolleman Island and Siple Dome, Antarctica, (Mulvaney and others, 1992; Kreutz and others, 1998) the concentration of $\mathrm{CH}_{3} \mathrm{SO}_{3}{ }^{-}$in the winter layer (which was relocated from the summer layer) determined whether sodium methanesulfonate or magnesium methanesulfonate formed at a depth of several meters. The temperatures of the cores at $10 \mathrm{~m}$ depth were $-16.8^{\circ} \mathrm{C}$ and $-25^{\circ} \mathrm{C}$ at Dolleman Island and Siple Dome respectively, suggesting that deeper ice might be at even higher temperatures. Taking into consideration our data on the eutectic temperatures of methanesulfonate salts, $\mathrm{CH}_{3} \mathrm{SO}_{3} \mathrm{Na} \cdot n \mathrm{H}_{2} \mathrm{O}\left(-29.3^{\circ} \mathrm{C}\right)$ could not be present in the Dolleman Island ice core but $\left(\mathrm{CH}_{3} \mathrm{SO}_{3}\right)_{2} \mathrm{Mg} \cdot n \mathrm{H}_{2} \mathrm{O}\left(-5.0^{\circ} \mathrm{C}\right)$ should be.

The annual surface temperature (e.g. 1996/97) on the Dome Fuji ice sheet ranges from $-79.7^{\circ} \mathrm{C}$ to $-18.6^{\circ} \mathrm{C}$, with a mean of $-54.4^{\circ} \mathrm{C}$ (Yamanouchi and others, 2003). The annual average surface temperature during the LGM has been determined from stable-isotope studies as roughly $-60^{\circ} \mathrm{C}$ (Watanabe and others, 2003). There should also have been a seasonal variation around this mean. From previous studies, $\mathrm{Na}^{+}$is the most abundant ion, while $\mathrm{Mg}^{2+}$ and $\mathrm{CH}_{3} \mathrm{SO}_{3}{ }^{-}$are minor ions in both periods, i.e. during the LGM and in current times (e.g. Watanabe and others, 2003; lizuka and others, 2004, 2006). Thus, these previous studies suggest that $\mathrm{CH}_{3} \mathrm{SO}_{3} \mathrm{Na} \cdot n \mathrm{H}_{2} \mathrm{O}$ can form at the surface of the Dome Fuji ice during both periods, and that 

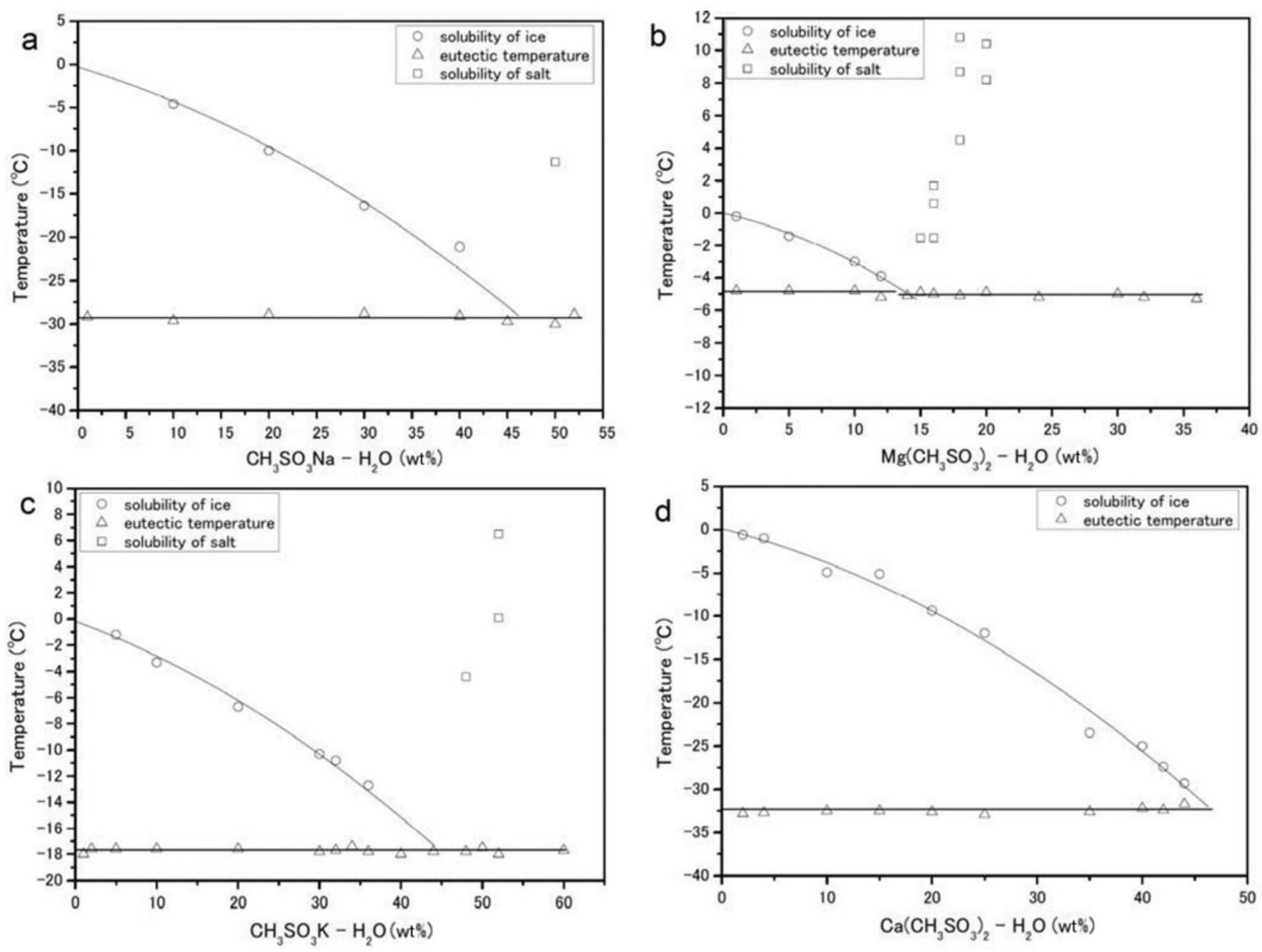

Fig. 5. Phase diagrams (eutectic temperatures are given in parentheses) constructed from DSC measurements. (a-d) correspond to $\mathrm{CH}_{3} \mathrm{SO}_{3} \mathrm{Na}-\mathrm{H}_{2} \mathrm{O}\left(-29.3 \pm 0.2^{\circ} \mathrm{C}\right), \quad\left(\mathrm{CH}_{3} \mathrm{SO}_{3}\right)_{2} \mathrm{Mg}-\mathrm{H}_{2} \mathrm{O}\left(-5.0 \pm 0.5^{\circ} \mathrm{C}\right), \mathrm{CH}_{3} \mathrm{SO}_{3} \mathrm{~K}-\mathrm{H}_{2} \mathrm{O}\left(-17.8 \pm 0.1^{\circ} \mathrm{C}\right)$ and $\left(\mathrm{CH}_{3} \mathrm{SO}_{3}\right)_{2} \mathrm{Ca}_{-} \mathrm{H}_{2} \mathrm{O}$ $\left(-32.6 \pm 0.2^{\circ} \mathrm{C}\right)$ respectively. The circles, triangles and squares trace the solubility of ice, the eutectic temperature and the solubility of salt respectively.

$\left(\mathrm{CH}_{3} \mathrm{SO}_{3}\right)_{2} \mathrm{Mg} \cdot n \mathrm{H}_{2} \mathrm{O}$ is probably a minor compound in the Dome Fuji ice core. However, among the 758 microparticles analyzed, we found no methanesulfonate salts except for $\left(\mathrm{CH}_{3} \mathrm{SO}_{3}\right)_{2} \mathrm{Mg} \cdot n \mathrm{H}_{2} \mathrm{O}$ in LGM ice. The discrepancy can be explained by the surface temperature and acidity of the ice at the time it formed.

Taking into consideration the eutectic temperatures of the $\mathrm{Mg}$ and Na salts, LGM summer temperatures at the surface could have been high enough to melt $\mathrm{CH}_{3} \mathrm{SO}_{3} \mathrm{Na} \cdot n \mathrm{H}_{2} \mathrm{O}$ but not $\left(\mathrm{CH}_{3} \mathrm{SO}_{3}\right)_{2} \mathrm{Mg} \cdot n \mathrm{H}_{2} \mathrm{O}$. Furthermore, $\mathrm{CH}_{3} \mathrm{SO}_{3} \mathrm{H}$ might sublimate from the firn after the $\mathrm{CH}_{3} \mathrm{SO}_{3} \mathrm{Na} \cdot n \mathrm{H}_{2} \mathrm{O}$ melts, lowering the concentration of $\mathrm{CH}_{3} \mathrm{SO}_{3}{ }^{-}$in the ice. This situation, dominant in the Holocene and in Termination $\mathrm{I}$, suggests that $\left(\mathrm{CH}_{3} \mathrm{SO}_{3}\right)_{2} \mathrm{Mg} \cdot n \mathrm{H}_{2} \mathrm{O}$ could have formed in the Holocene and Termination I sections of the Dome Fuji ice core. According to previous studies of the firn, however, sulfuric acid and sea salt can combine to produce sulfate salts (lizuka and others, 2006). The high acidity of Holocene and Termination I ice (Fujita and others, 2002) may have allowed the reaction

$$
\mathrm{H}_{2} \mathrm{SO}_{4}+\left(\mathrm{CH}_{3} \mathrm{SO}_{3}\right)_{2} \mathrm{Mg} \rightarrow \mathrm{MgSO}_{4}+2 \mathrm{CH}_{3} \mathrm{SO}_{3} \mathrm{H}
$$

to occur during the post-depositional process, eliminating $\left(\mathrm{CH}_{3} \mathrm{SO}_{3}\right)_{2} \mathrm{Mg} \cdot n \mathrm{H}_{2} \mathrm{O}$ particles from the ice.
In the LGM ice, methanesulfonate salts form by fixation on alkaline particles of marine or continental origin during longrange aerosol transport to polar areas (Delmas and others, 2003). During this period, high levels of dust neutralized the acids, greatly reducing their abundance (Röthlisberger and others, 2003; lizuka and others, 2008). This neutralization of the LGM ice permits the existence of $\left(\mathrm{CH}_{3} \mathrm{SO}_{3}\right)_{2} \mathrm{Mg} \cdot n \mathrm{H}_{2} \mathrm{O}$.

To summarize, we propose that $\left(\mathrm{CH}_{3} \mathrm{SO}_{3}\right)_{2} \mathrm{Mg} \cdot n \mathrm{H}_{2} \mathrm{O}$ may have formed in the air and been transported as an aerosol. The salt was then deposited on the ice sheet, where it had a chance to survive and be preserved in LGM ice because the acids were neutralized.

\section{CONCLUSION}

We found $\left(\mathrm{CH}_{3} \mathrm{SO}_{3}\right)_{2} \mathrm{Mg} \cdot n \mathrm{H}_{2} \mathrm{O}$ in the LGM ice from Dome Fuji, and this salt is restricted to the coldest period in the glacial cycle. Our study suggests that $\left(\mathrm{CH}_{3} \mathrm{SO}_{3}\right)_{2} \mathrm{Mg} \cdot n \mathrm{H}_{2} \mathrm{O}$ formed in the atmosphere of Antarctica. In acidic Holocene ice, however, $\left(\mathrm{CH}_{3} \mathrm{SO}_{3}\right)_{2} \mathrm{Mg} \cdot n \mathrm{H}_{2} \mathrm{O}$ was dissolved by acid after being deposited. Only during the LGM did $\left(\mathrm{CH}_{3} \mathrm{SO}_{3}\right)_{2} \mathrm{Mg} \cdot n \mathrm{H}_{2} \mathrm{O}$ that formed in the atmosphere have a chance to survive on the ice sheet and be preserved in the Dome Fuji ice core. 


\section{ACKNOWLEDGEMENTS}

We thank all participants in the Dome Fuji ice-core drilling project. We also thank A. Hori and A. Miyamoto for valuable discussions, and the scientific editor B. Kulessa. This study was supported by Grants-in-Aid for Creative Scientific Research (grant Nos. 14 GS0202 and 21710002), by the Global COE program (Establishment of Center for Integrated Field Environmental Science) and by a Special Education Study Expense fund (for cooperation between universities) provided by the Ministry of Education, Culture, Sports, Science and Technology (MEXT) and the Japan Society for the Promotion of Science (JSPS), Japan.

\section{REFERENCES}

Barletta, R.E., B.N. Gros and M.P. Herring. 2009. Analysis of marine biogenic sulfur compounds using Raman spectroscopy: dimethyl sulfide and methane sulfonic acid. J. Raman Spectrosc., 40(8), 972-981.

Charsley, E.L. 1993. Introduction to the work of the ICTAC Committee on Standardisation. J. Therm. Anal. Calor., 40(3), 1399-1404.

Curran, M.A.J., T.D. van Ommen, V.I. Morgan, K.L. Phillips and A.S. Palmer. 2003. Ice core evidence for Antarctic sea ice decline since the 1950s. Science, 302(5648), 1203-1206.

Delmas, R.J., P. Wagnon, K. Goto-Azuma, K. Kamiyama and O. Watanabe. 2003. Evidence for the loss of snow-deposited MSA to the interstitial gaseous phase in central Antarctic firn. Tellus, 55B(1), 71-79.

Durig, J.R., L. Zhou, T. Schwartz and T. Gounev. 2000. Fourier transform Raman spectrum, vibrational assignment and ab initio calculation of methanesulfonic acid in the gas and liquid phases. J. Raman Spectrosc., 31(3), 193-202.

Fujita, S., H. Maeno, T. Furukawa and K. Matsuoka. 2002. Scattering of VHF radio waves from within the top $700 \mathrm{~m}$ of the Antarctic ice sheet and its relation to the depositional environment: a case study along the Syowa-Mihuzo-Dome Fuji traverse. Ann. Glaciol., 34, 157-164.

Genceli, F.E. and 6 others. 2009. Meridianiite detected in ice. J. Glaciol., 55(189), 117-122.

Hondoh, T., H. Shoji, O. Watanabe, A.N. Salamatin and V.Y. Lipenkov. 2002. Depth-age and temperature prediction at Dome Fuji station, East Antarctica. Ann. Glaciol., 35, 384-390.

Hynes, A.J., P.H. Wine and D.H. Semmes. 1986. Kinetics and mechanism of $\mathrm{OH}$ reactions with organic sulfides. J. Phys. Chem., 90(17), 4148-4156.

lizuka, Y. and 6 others. 2004. Chemical characteristics in a 22-m ice core on the Belukha Glacier, Russia. Polar Meteorol. Glaciol., 18, 114-120.

lizuka, Y., T. Hondoh and Y. Fujii. 2006. $\mathrm{Na}_{2} \mathrm{SO}_{4}$ and $\mathrm{MgSO}_{4}$ salts during the Holocene period derived by high-resolution depth analysis of a Dome Fuji ice core. J. Glaciol., 52(176), 58-64.

lizuka, Y. and 6 others. 2008. A relationship between ion balance and the chemical compounds of salt inclusions found in the Greenland Ice Core Project and Dome Fuji ice cores. J. Geophys. Res., 113(D7), D07303. (10.1029/2007JD009018.)

Jaffrezo, J.L., C.I. Davidson, M. Legrand and J.E. Dibb. 1994. Sulfate and MSA in the air and snow on the Greenland ice sheet. J. Geophys. Res., 99(D1), 1241-1253.

Kreutz, K.J., P.A. Mayewski, S.I. Whitlow and M.S. Twickler. 1998. Limited migration of soluble ionic species in a Siple Dome, Antarctica, ice core. Ann. Glaciol., 27, 371-377.
Legrand, M. and C. Feniet-Saigne. 1991. Methanesulfonic acid in south polar snow layers: a record of strong El Niño? Geophys. Res. Lett., 18(2), 187-190.

Legrand, M., C. Feniet-Saigne, E.S. Saltzman, C. Germain, N.I. Barkov and V.N. Petrov. 1991. Ice-core record of oceanic emissions of dimethylsulphide during the last climate cycle. Nature, 350(6314), 144-146.

Legrand, M., C. Feniet-Saigne, E.S. Saltzman and C. Germain. 1992. Spatial and temporal variations of methanesulfonic acid and non sea salt sulfate in Antarctic ice. J. Atmos. Chem. 14(1-4), 245-260.

McMorrow, A.J., T.D. van Ommen, V. Morgan and M.A.J. Curran. 2004. Ultra-high-resolution seasonality of trace-ion species and oxygen isotope ratios in Antarctic firn over four annual cycles. Ann. Glaciol., 39, 34-40.

Mulvaney, R., E.C. Pasteur, D.A. Peel, E.S. Saltzman and P.Y. Whung. 1992. The ratio of MSA to non-sea-salt sulphate in Antarctic Peninsula ice cores. Tellus, 44B(4), 295-303.

Ohno, H., A. Igarashi and T. Hondoh. 2005. Salt inclusions in polar ice core: location and chemical form of water-soluble impurities. Earth Planet. Sci. Lett., 232(1-2), 171-178.

Ohno, H., M. Igarashi and T. Hondoh. 2006. Characteristics of salt inclusions in polar ice from Dome Fuji, East Antarctica. Geophys. Res. Lett., 33(8), L08501. (10.1029/2006GL025774.)

Pasteur, E.C. and R. Mulvaney. 1999. Laboratory study of the migration of methane sulphonate in firn. J. Glaciol., 45(150), 214-218

Pasteur, E.C. and R. Mulvaney. 2000. Migration of methane sulphonate in Antarctic firn and ice. J. Geophys. Res., 105(D9), 11,525-11,534

Rankin, A.M., E.W. Wolff and S. Martin. 2002. Frost flowers: implications for tropospheric chemistry and ice core interpretation. J. Geophys. Res., 107(D23), 4683. (10.1029/ 2002JD002492.)

Röthlisberger, R. and 8 others. 2003. Limited dechlorination of sea salt aerosols during the last glacial period: evidence from the EPICA Dome C ice core. J. Geophys. Res., 108(D16), 4256. (10.1029/2003JD003604.)

Ruth, U. and 6 others. 2004. Comprehensive 1000 year climatic history from an intermediate-depth ice core from the south dome of Berkner Island, Antarctica: methods, dating and first results. Ann. Glaciol., 39, 146-154.

Saigne, C. and M. Legrand. 1987. Measurements of methanesulphonic acid in Antarctic ice. Nature, 330(6145), 240-242.

Sakurai, T., H. Ohno, S. Honikawa, Y. lizuka, T. Uchida and T. Hondoh. In press. A technique for measuring microparticles in polar ice using micro-Raman spectroscopy. Int. J. Spectrosc. (10.1155/2010/384956.)

Saltelli, A. and J. Hjorth. 1995. Uncertainty and sensitivity analyses of $\mathrm{OH}$-initiated dimethyl sulphide (DMS) oxidation kinetics. J. Atmos. Chem., 21(3), 187-221.

Smith, B.T., T.D. van Ommen and M.A.J. Curran. 2004. Methanesulphonic acid movement in solid ice cores. Ann. Glaciol., 39, 540-544.

Socrates, G. 2001. Infrared and Raman characteristic group frequencies: tables and charts. Third edition. Chichester, John Wiley \& Sons.

Watanabe, O., J. Jouzel, S. Johnsen, F. Parrenin, H. Shoji and N. Yoshida. 2003. Homogeneous climate variability across East Antarctica over the past three glacial cycles. Nature, 422(6931), 509-512.

Wunderlich, B. 1973. Analysis by calorimetry. Thermochim. Acta, 5(4), 369-376.

Yamanouchi, T., N. Hirasawa, M. Hayashi, S. Takahashi and S. Kaneto. 2003. Meteorological characteristics of Antarctic inland station, Dome Fuji. Mem. Natl Inst. Polar Res. 57, Special Issue, 94-104. 